Vol. 2, No. 1, Januari - Juni 2018

\title{
edureligia
}

\section{URGENSI EVALUASI PEMBELAJARAN DALAM PENDIDIKAN}

\author{
Moh. Fachri ${ }^{1}$ \\ Universitas Nurul Jadid Probolinggo, Indonesia
}

\section{Info Artikel}

Sejarah Artikel:

Diterima; December 2017

Disetujui; Januari 2017

Dipublikasikan; Maret

2018

Keywords:

urgency;evaluation;

education

\begin{abstract}
Learning process is the most important part in education as an effort to mature learners, The success of the learning process becomes a benchmark achievement oflearning objectives. To know the achievement of the success of learning objectives, it must be done evaluation / assessment. In particular the purpose of evaluation to determine the progress of learning outcomes of learners after following the learning, as well as to determine the level of effectiveness and efficiency of methods, strategies that teachers use in learning. Evaluation of learning has an important and strategic meaning in education, because the learning process becomes meaningful, as well as its evaluation results can be used as a basis to determine the next step, for teachers, principals, institutions, parents, and government. The importance oflearning evaluation can be seen from the approach of the learning process, the characteristics of professional educators, and the institutional approach, but it can also be seen from its purpose, function and principles and the validity and reliability of its evaluation tool.
\end{abstract}




\section{PENDAHULUAN}

Proses pembelajaran merupakan bagian terpenting dalam pendidikan sebagai upaya mendewasakan peserta didik, sebagaimana dinyatakan Langeveld $(2005,2)$ bahwa pada dasarnya pendidikan bertujuan untuk mendewasakan anak/peserta didik. Dengan demikian, proses pembelajaran menjadi kunci bagi keberhasilan pendidikan itu sendiri. Oleh karena itu, pelaksanaan proses pembelajaran harus benar-benar diefektif kan dan harus berjalan sesuai dengan tujuan pembelajaran yang telah ditetapkan sebe lumnya.

Atas dasar pemikiran tersebut, maka menurut Bloom dalam taksonominya bahwa sasaran proses pembelajaran yang dilaksanakan harus mengarah kepada tiga ranah dari peserta didik, yaitu : Ranah Kognitif, Ranah Afektif, Ranah Psikomotorik.

Menurut Ramayulis (2005 : 24) Garapan masing-masing ranah seperti disebutkan diatas dapat dijelaskan sebagai berikut :

\section{Kognitif}

Domain ini mencakup enam daerah garapan, yaitu; Pengetahuan, yaitu kemampuan mengingat konsep-konsep yang khusus dan yang umum, baik menyangkut proses, metode, maupun struktur; Pemahaman, yaitu kemampuan memahami tanpa mengetahui hubungan-hubungannya dengan yang lain, juga tanpa kemampuan mengaplikasikan pemahaman tersebut; Aplikasi, yaitu kemampuan menggunakan konsep-konsep abstrak pada obyek-obyek khusus dan konkret, baik berupa ide-ide umum, prosedur prinsip-prinsip teknis, atau teori yang harus diaplikasikan; Analisis, yaitu kemampuan memahami dengan jelas hirarkhi ide-ide dalam suatu unit bahan atau dapat menerangkan dengan jelas tentang hubungan ide-ide yang satu dengan yang lainnya; Sintesis, yaitu kemampuan menggabungkan bagian-bagian menjadi satu dengan utuh, sehingga menjadi sebuah struktur yang jelas; Evaluasi, yaitu kemampuan dalam mempertimbangkan nilai bahan dan metode yang digunakan dalam menyelesaikan suatu problem.

\section{Afektif}

Domain ini mencakup lima daerah garapan, yaitu; Memperhatikan, yaitu memperhatikan pembinaan dan pemberian nilai-nilai yang diajarkan dengan kesediaannya menggabungkan diri ke dalam nilai-nilai yang diajarkan tersebut; Merespon, yaitu pembinaan melalui upaya motivasi agar peserta didik mau menerima nilai yang diajarkan. Selain menerima nilai, pada diri peserta didik juga memiliki daya yang mendorong diri untuk menerima ajaran yang ajarkan kepadanya; Nilai, yaitu pembinaan yang diarahkan untuk mampu menilai konsep atau fenomena apakah ia baik atau buruk; Organisasi / menghayati nilai, yaitu pembinaan untuk mengorganisasikan nilai ke dalam suatu sistem dan menentukan hubungan antara nilai-nilai tersebut, serta menentukan nilai yang dominan untuk diinternalisasikan ke dalam kehidupan nyata; Mempribadikan nilai, yaitu pembinaan untuk menginternalisasikan nilai sebagai puncak hirarki nilai yang tertanam secara konsisten pada sistem di dalam dirinya, efektif mengontrol tingkah laku dirinya serta mempengaruhi emosinya.

\section{Psikomotor}

Dominan ini memiliki tujuh daerah garapan yaitu; Persepsi, yaitu keterampilan dalam menggunakan organ-organ indera untuk memperoleh petunjuk yang membimbing kegiatab motorik; Kesiapan, yaitu keterampilan kesiapan untuk melakukan kegiatan khusus, yang meliputi kesiapan mental, phisik maupun kemauan untuk bertindak; Respon terbimbing, yaitu keterampilan respon terpimpin dalam melakukan hal-hal yang kompleks, seperti : menirukan dsb. Keterampilan mekanis, yaitu merupakan pekerjaan yang menunjukkan bahwa respon yang dipelajari telah menjadi kebiasaan dan gerakan-gerakan dapat dilakukan dengan penuh kemahiran; Respon kompleks, yaitu keterampilan nyata gerakan motor yang menyangkut penampilan yang sangat terampil dari gerakan motoriknya. Kemahiran ditunjukkan seperti kecepatan lancar dan tepat dsb; Adaptasi, yaitu keterampilan untuk mengubah pola gerakannya untuk disesuaikan dengan persyaratan khusus dalam situasi tertentu; Organisasi, yaitu keterampilan yang menyangkut pola-pola gerakan yang baru untuk menyesuaikan dengan situasi yang khusus atau yang bermasalah.

Ketiga domain tersebut dapat dikristalisasikan menjadi tiga bagian, yaitu; Dimensi kepribadian sebagai maunusia, yaitu kemampuan untuk menjaga integritas antara sikap, tingkah laku etik, dan moralitas. Dimensi produktifitas, yang menyangkut apa yang dihasilkan peserta didik dengan kualitas yang lebih baik setelah mereka menamatkan sekolah, Dimensi kreatifitas yang menyangkut kemampuan peserta didik untuk berfikir dan 
berbuat, menciptakan sesuatu yang berguna bagi diri sendiri dan masyarakat

Dari ketiga domain tersebut di atas dapat dikristalisasikan menjadi tiga bagian, yaitu:

Dimensi kepribadian sebagai manusia, yaitu kemampuan untuk menjaga integritas antara sikap, tingkah laku etik, dan moralitas.

Dimensi produktifitas yang menyangkut apa yang dihasilkan peserta didik dalam jumlah yang lebih banyak dan kualitas yang lebih baik setelah ia menamatkan pendidikan.

Dimensi kreatifitas yang menyangkut kemampuan peserta didik untuk berfikir dan berbuat, menciptakan sesuatu yang bergguna bagi diri sendiri dan masyarakat.

Untuk mencapai sasaran kepada tiga ranah tersebut sebagai upaya pembentukan kompetensi dasar peserta didik, maka diperlukan metode, strategi/model pembelajaran, dan media pembelajaran yang disesuaikan dengan tujuan pembelajaran yang telah dirumuskan sebelumnya.

Keberhasilan proses pembelajaran menjadi tolak ukur tercapainya tujuan pembelajaran. Untuk mengetahui calpaian Reberhasilana proses pembelajaran dan pembentukan kompetensi peserta didik sebagai tujuan pembelajaran maka harus dilakukan evaluasi/penilaian. Mengapa diperlukan evaluasi? Apa urgensinya terkait dengan pendidikan?

\section{KONSEP-KONSEP YANG RELEVAN}

\section{Pengertian Evaluasi Pembelajaran}

Evaluasi dalam artian bahasa menurut M.Chabib thoha $(1990: 1)$ berarti penilaian sebagai terjemahan dari bahasa Inggris evaluation. Sedangkan dalam dalam artian definitif adalah Kegiatan yang terencana untuk mengetahui keadaan suatu obyek dengan menggunakan instrumen dan hasilnnya diperbandingkan dengan tolak ukur untuk memperoleh kesimpulan (Muali, 2009).

Dengan demikian, evaluasi bukan sekedar menilai suatu aktivitas secara spontan dan insidental, melainkan merupakan kegiatan untuk menilai sesuatu secara terencana, sistematik, dan terarah berdasarkan tujuan yang jelas.

Sedangkan menurut Depdikbud dalam Zainal Arifin ( 2016: 4 ) Penilaian adalah suatu kegiatan untuk memberikan berbagai informasi secara berkesinambungan dan menyeluruh tentang proses dan hasil yang telah diperoleh siswa. Kata menyeluruh mengandung arti bahwa penilaian tidak hanya ditujukan pada pengusaan salah satu bidang tertetu saja, tetapi mencakup aspek pengetahuan, sikap, keterampilan dan nilainilai.

Menurut Ralph Tyler dalam Suharsimi Arikunto ( 2009 : 3 ) evaluasi merupakan sebuah proses pengumpulan data untuk menentukan sejauh mana, dalam hal apa, dan bagian mana tujuan pendidikan sudah tercapai. Jika belum, bagaimana yang belum dan apa sebabnya.

Selanjutnya menurut Grounlund dalam M.Ainin (2006 : 3 ) mengartikan evaluasi adalah suatu proses yang sistematis dalam mengumpulkan, menganalisis, dan menafsirkan data-data untuk menentukan apakah peserta didik dipandang telah mencapai target pengetahuan dan keterampilan yang dirumuskan dalam tujuan pembelajaran.

Dengan kata lain, evaluasi adalah proses mengumpulkan data untuk mengambil keputusan dengan menggunakan pertimbangan-pertimbagan nilai.

Sebagaimana juga dinyatakan Cronbach dan Staffle Beam dalam Suharsimi Arikunto ( 2009 : 3 ) bahwa evaluasi bukan sekedar mengukur sejauh mana tujuan tercapai, tetapi digunakan untuk membuat keputusan.

Dengan demikian, dapat disimpulkan bahwa penilaian adalah suatu proses atau kegiatan yang terencana, sistematis dan berkesinambungan untuk mengetahui keadaan suatu obyek dengan mengumpulkan informasi tentang proses dan hasil belajar peserta didik dalam rangka membuat keputusan-keputusan berdasarkan kriteria dan pertimbangan tertentu. Keputusan yang dimaksud adalah keputusan tentang peserta didik, seperti nilai yang akan dberikan atau juga keputusan tentang kenaikan kelas dan kelulusan.

Ada istilah lain yang mirip dengan Evaluasi/ Penilaian yaitu Pengukuran/Measurement yang menurut M.Chotib Thoha (1990:2 ) mengandung arti menurut Wondt,Edwin And G.W. Brown adalah Proses untuk menentukan luas atau kuantitas sesuatu.

Dengan pengertian lain pengukuran adalah usaha untuk mengetahui sesuatu seperti adanya yang dapat dikuantitaskan.

Unsur-unsur pokok yg harus ada dlm kegiatan pengukuran adalah :

1.Adanya obyek yg diukur

2.Adanya tujuan pengukuran

3.Adanya alat ukur

4.Adanya proses pengukuran

5.Adanya hasil pengukuran (kuantitatif)

Unsur pokok dlm penilaian selain menca kup kegiatan pengukuran mencakup pula 
6.Adanya standar yang dijadikan
pembanding.

7.Adanya proses perbandingan antara hasil pengukuran dengan standart

8.Adanya hasil penilaian (kualitatif)

Sedangkan menurut Zainal Arifin ( $2016: 4$ ) pengukuran adalah suatu proses atau kegiatan untuk menentukan kuantitas sesuatu. Kata sesuatu bisa berarti peserta didik, guru, gedung sekolah, meja belajar , white board, dsb.

Dalam proses pengukuran tentu guru harus menggunakan alat ukur. Alat ukur tersebut harus standar, yaitu harus memiliki derajat validitas dan reliabilitas yang tinggi. Dalam bidang pendidikan, psikologi, maupun variable-variabel sosial lainnya kegiatan pengukuran biasanya meggunakan tes.

Selanjutnya menurut Gronlund dan Linn (1985:5 ) Measurement is the process of obtaining a numerical description of the degree to wich individual processes a particular characteristic. It answers the question "How much"? Artinya: Pengukuran adalah suatu proses untuk memperoleh deskripsi dalam bentuk angka-angka mengenai tingkat dari sifat atau kemampuan yang dimiliki seseorang. Pengükuranna merupakan suatu konsep yang bermakna proses menerapkan angka-angka kepada benda atau gejala berdasarkan aturan-aturan yang telah ditetapkan. Dengan demikian, dapat dikatakan bahwa pengukuran adalah suatu tindakan untuk menentukan jumlah atau kuantitas dari sesuatu.

Dari urian di atas, dapat difahami bahwa pengukuran merupakan bagian dari evaluasi yang berupa prosedur pengumpulan data dan informasi numerik yang diperlukan sebagai salah satu pertimbangan pengambilan keputusan dalam evaluasi.

Sebagaimana hal ini juga dinyatakan Wayan Nurkancana ( 1986:2 ) Walaupun ada perbedaan antara penilaian dan pengukuran, namun kedua hal tersebut tidak dapat dipisahkan karena antara pengukuran dan penilaian terdapat hubungan yang sangat erat. Sebab, untuk mengadakan penilaian yang tepat terhadap sesuatu terlebih dahulu harus didasarkan atas pengkuranpengukuran. Misalnya, untuk menilai apakah seorang anak dapat membaca dengan lancar atau tidak, maka kita harus mengukur berapa jumlah kata-kata yang dapat dibacanya dalam tempo satu menit, berapa kesalahankesalahan yang dibuatnya, dan sebagainya. Sebaliknya pengukuran -pengukuran yang dilakukan tidak akan memberi arti apa-apa kalau tidak kita hubungkan dengan penilaian.
Pengertian pendidikan

Pengertian pendidikan menurut Ramayulis ( 2010 : 13 ) Pendidikan berarti bimbingan atau pertolongan yang diberikan dengan sengaja terhadap anak didik oleh orang dewasa agar ia menjadi dewasa.

Menurut Sudirman, N. ( 1991 : 4 ) Pendidikan berarti usaha yang dijalankan oleh seseorang atau sekelompok orang untuk mempengaruhi seseorang atau sekelompok orang agar menjadi dewasa atau mencapai tingkat hidup dan penghidupan yang lebih tinggi dalam arti mental.

Selanjutnya menurut Freeman Butt dalam Zinal Arifin ( 2016: 38 ) menyatakan :

1.Pendidikan adalah kegiatan menerima dan memberikan pengetahhuan, sehingga kebudayaan dapat diteruskan dari generasi ke generasi berikutnya.

2.Pendidikan adalah suatu proses. Melalui proses ini individu diajarkan kesetiaan dan kesediaan untuk mengikuti aturan. Melalui cara ini pikiran manusia dilatih dan dikembangkan.

\section{DAFTAR PUSTAKA}

Arifin, Zainal, 2016, Evaluasi Pembelajaran, na IslanBandung : PT Remaja Rosda Karya

Arikunto,Suhsrsimi, 2009, Dasar-dasar
Evaluasi Pendidikan, Jakarta : PT Bumi
Aksara
Ainin, M, et.al, 2006, Evaluasi Dalam
Pembelajaran Bahasa Arab, Malang :
Misykat \& Linn Robert,L, 19985,
Gronlund,N.E \&
Measurement and Evaluation in
teaching, New York : Macmillan
Publishing co.
Hasbullah. 2005, Dasar-dasar ilmu Pendidikan, Jakarta : PT Raja Grafindo Persada

Muali, C. 2009. Pengaruh Penggunaan Komputer Multimedia dan Gaya Belajar Terhadap Hasil Belajar Fisika Siswa Kelas VII SMP Negeri Besuk Probolinggo. Proceeding Improving Teachers Professional to Face The Global Education Challenges. 1(1)132139

Nurkancana,wayan, 1986, Evaluasi Pendidikan, Surabaya : Usaha Nasional

N. Sudirman et.al, 1991, Imu Pendidikan, Bandung : PT Remaja Rosda Karya

Ramayulis, 2010, Ilmu Pendidikan Islam, Jakarta : Kalam Mulya

Ramayulis,2005, Metodologi Pendidikan Agama islam, Jakarta : Kalam Mulya

Syah,Muhibbin, 2009, Psikologi Belajar, Jakarta : PT Raja Grafindo Persada 
Thoha,M. Chabib, 1990, Teknik Evaluasi

Pendidikan, Jakarta : PT Raja Grafindo

Persada

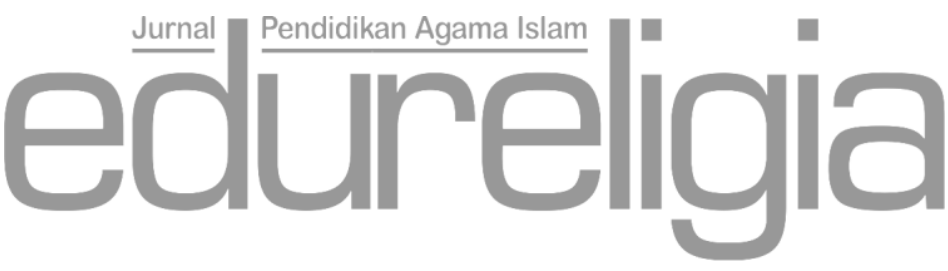

